\title{
EDUCATIONAL SPORT FOR CHILDREN AND TEENAGERS: REFLECTIONS AND EXPERIENCES
}

\author{
Deyvid Tenner de Souza Rizzo ${ }^{1 *}$; Rogério Zaim de Melo ${ }^{1}$; Ana Paula Moreira de Sousa ${ }^{2}$ Diogo Silva \\ Correa $^{3}$; Eder Rodrigo Mariano ${ }^{4}$ \\ 1. Federal University of Mato Grosso do Sul, Corumbá - MS, 79304-902, Brazil \\ 2. Federal University of Grandes Dourados, Vila Progresso, Dourados -MS, 79825-070, Brazil \\ 3. Federal University of Maranhão, Pinheiro - MA, 65200-000, Brazil \\ 4. Lusophone University of Humanities and Technologies, Lisboa, 1749-024, Portugal. \\ e-mail*: deyvidrizzo1@gmail.com
}

\begin{abstract}
Purpose: the objective of the survey is to analyze the development of sports activities promoted on the context of a sportive center, thus identidy sports' influence on the students' life that practice sports.

Methodology/Approach: the research is qualitative and quantitative by nature, and questionaires were applied to properly registered students on any sport modality.

Findings: the investigation demonstrates that educational sportive program participant children and teenagers reveal informations that promote homogeneous sport.

Research Limitation/implication: it is considered that the teachers' pedagogical treatment with the sportive activities may influence the stay and continuance of students in the practice of sports, however, future studies may consider the coaches in the sample of subjects.
\end{abstract}

Originality/Value of paper: the originality of the survey points to the need of investigating about the children and teenagers sports teaching professional's role.

KEYWORDS: physical education, health science, sports pedagogy.

\section{ESPORTE EDUCACIONAL PARA CRIANÇAS E ADOLESCENTES: REFLEXÕES E EXPERIÊNCIAS}

\section{RESUMO}

Objetivo: o objetivo do estudo é analisar o desenvolvimento de práticas esportivas educacionais promovidas no contexto de um centro esportivo, com isso identificar a influência do esporte na vida dos alunos que praticam esportes.

Metodologia: a pesquisa é de natureza quali-quantitativa, e foram aplicados questionários para os alunos devidamente matriculados em alguma modalidade esportiva.

Achados: a investigação do estudo demonstra que crianças e adolescentes participantes de programas esportivos educacionais revelam informações que favorecem para a desconstrução do esporte homogêneo.

Limitações da pesquisa: considera-se que o tratamento pedagógico do professor para as atividades esportivas pode influenciar para a permanência e continuidade dos alunos na prática de esportes, contudo, futuros estudos podem considerar os treinadores na amostra de sujeitos.

Originalidade: a originalidade do estudo permite apontar a necessidade de investigações acerca do papel dos profissionais que ensinam esportes para crianças e adolescentes.

PALAVRAS-CHAVE: educação física, ciências da saúde, pedagogia do esporte. 


\section{INTRODUCTION}

The manner that the sport sets on people's life nowadays is object of investigation of several studies (BARBOSA and ARAÚJO, 2015; BARRETO and PERFEITO, 2018; BELTRAME et al., 2015; BENELI, PRONI, MONTAGNER, 2016; FREITAS and STIGGER, 2016). The educational sport is not just the practiced on the school, but a much bigger proposal that the school sport, since this action strives to reproduce positive values capable of conduct people to replicate a "high performance" for life, experiencing the diferente abilities of the other, considernig the specificities of the movement of each one and, above all, living and respecting everyone's inabilities.

The general objective of the survey is to analyze the influence of the educational sport pratice promoted by a public centre of sports practice. It also lens to indentify the positive effects and perhabs the negatives of the presence of sport on its students' life. To the analysis, it was applied a semi-structured questionnaire to a group of 75 children and teenagers among boys and girls.

The sport pedagogy emmerges as a rising knowledge area on the studies directed to the various sportive practice teaching. (BRASIL et al., 2017; FLORES, RIZZO, VALENÇOELA, 2019; MACHADO, GALATTI et al, 2014; PAES, 2015; SOARES, MILLEN NETO, FERREIRA, 2013). Hence, the study about educational sports proves importante to the society, above all when we think about the new generations, in charge of, in the first instance, the future social changes and of the renovation of values and traditions. If the traditions are in a constant reconstruction, new values will arise, not always that positive or selfless as ethically wanted. It is imposed then the moral responsability of the general society, with emphasis on the family, on the school and other institutions encharged of formaly educating young people, by the proccess of positive value transmission.

The present study assumes that sportive practice is a fenomenon rich of meanings and is also a reflexion of a cultural and historical society construction, and must be treated on the "sport pedagogy" view (Rizzo, 2017; Galatti et al., 2018; Leonardi et al., 2017; Paes and Balbino, 2005; Scaglia, 2014) to accompany the humanity progress and overlap segregating practices that propel children and young people's life to regression.

By pleading a position that the sport (Machado, 2017; Rizzo et al., 2016a, Rizzo et al., 2016b; Vianna and Lovisolo, 2009) can result a good work to everyone developed by educational sport we encountered with the need of pointing paths that lead to this purpose. These paths are outlined from the understanding that recreation, the playfulness, the game, among other manifestations, may become a conscious practice in the interior of educational sport, reporting a fusion between delight and sport.

Sport for everyone or for almost everyone? This question motivated us to write this text, united to the desire of demonstrating that educational intervention is necessary in the sports area. Thus, the proposal of a sport for everyone is an idea that has urged many investigations for decades in different parts of the world, however, what has been instigated us is the possibility that the sport is reaching almost everyone. This is the reason of the concern about educational values in the context of sports practice (FERREIRA, 2018; GO TANI et al., 2013; LUGUETTI et al., 2015; NASCIMENTO, RIZZO, SOUSA, 2017; SOARES, ANTUNES, AGUIAR, 2015).

We do not intend to tell the story or discuss the concept of sport for everyone, several authors such as Pazin et al. (2010); Fraga (2005); Linhares (2006) devoted theirselves to this laudably. We clarify that a discussion was developed directing the sport for all as a way of motivation in the process of systematization of the educational sport.

It must be understood that sport in our society manifests itself in different ways and in different spaces. To a better understanding about the sport phenomenon and how it is practiced today, Tubino (1996) classified it in the following dimensions: education-sport, sports-delightness and performance sports. 
Through the dimensions mentioned above, the sportive practice is able to produce the socialization of its participants and, consequently, reproduce meanings in its practice. This way, the analysis of the results shows that children and teenagers that frequent sports programs focused on an educational practice associate the feeling of self-overcoming, self-esteem, collectivity and respect with the performance of sports activities.

The research is divided into three sections, the first one to be presented in the introduction evinces the theoretical basis, the second one evinces the methodological structure of the study, finally, the third one presents, analyzes and discusses the main results of the investigation.

\section{MATERIALS AND METHODS}

Research approved by the Ethics and Research Committee from Federal University of Grande Dourados-MS (CAAE: 50341915.4.0000.5160/ Report number: 1.402.554). A qualiquantitative approach was chosen, since it is the most indicated to investigate problems that only statistical procedures are not enough to reach or to represent due to its complexity (LIMENA; RODRIGUES, 2006; MINAYO, 2004). These problems include social aspects, psychological, opinions, behaviors, attitudes of individuals or groups. For this analysis, the study sample comprised seventy five students (forty eight boys and twenty seven girls) properly registered in some sport modality (futsal, basketball, volleyball, muscle-building and judo; ages vary from 11 to 16 years old, and frequent sport-centered programs The sports center attends to children and teenagers from different socioeconomic and racial conditions.

It was sent an informed consent form and a study cover letter to the parents, which were completed correctly. Only after collecting the terms that the respective teachers, of different sports modalities, applied the questionnaire to the teenagers. Previously, the questionnaire was organized with a simple language for better visibility of the interviewees, and later validated by researchers in th e area, with closed and open questions, about the ways that these subjects mean the sports practices in which they are involved. The elaboration of the instrument of collected data used in the present study was especially validated from the evaluation of three specialists (doctors), designed to gather information that characterizes the students' perceptions about sportive practice. A pilot test was conducted, applying the questionnaire to eighteen students aged between 11 and 12 years old, registered in the futsal sport modality for possible improvements regarding the structure, organization, and procedures of application of the questionnaire. The final version of the semistructured questionnaire consisted of thirteen questions (open, closed and multiple choice).

The elaboration of the questionnaire used in the present study was based on the version of the questionnaire that the canadian Dany MacDonald (2012) proposes to researchers interested in the experiences of children and teenagers who practice some sport, the Youth Experience Survey for Sport (YES-S).

The technical advisor of the institution authorized the teachers to give the informed consent term for the students to take home and their guardians to sign in order to authorize or not their child to participate in the research. Then, the teachers of each sport modality collected the terms and applied the questionnaire to the students that were authorized by their guardians in a closed room without being under pressure. The time for students to respond varied from 12 and 35 minutes. After answering the questionnaires, the teachers stored them in an envelope and intended for the responsible researcher exactly the day after the application. 
The choosing process of participation on the study was open, i.e., subjects who were between 11 and 16 years old and who were participating in some sport modality in the analyzed institution could spontaneously participate in the study, thus totaling 75 deponents between boys and girls. Thus, we sought to record, analyze and interpret the students' answers in order to explore the universe of values, norms and representations of these subjects, stemming from their experiences in conducting sportive activities, respecting their verbalization skills in the answers to open questions.

\section{RESULTS AND DISCUSSIONS}

In Barreto and Perfeito's (2018) research, the results indicated that social inclusion projects through sport do not appear to influence individuals in the value construction, such as preventing adherence to crime that they are exposed. However, the results of the present survey indicate that adolescents participating of educational sports programs reveal information that favors the deconstruction of homogeneous sports, and through subjective values in sportive practice of educational character, the subjects manifest positive values transferable to other instances of life.

All study subjects of the study believe that everyone can practice sports. The following chart 1 demonstrates some reasons why students would "continue or stop" practicing sports.

Chart 1: Reasons that would cause students to continue or stop playing sports.

\begin{tabular}{|c|c|}
\hline Continue practicing sports & Stop practicing sports \\
\hline Make more friends & Violence \\
\hline Improve my health & Bullying \\
\hline Be a professional player & Boring Coach \\
\hline Win trophies & If I hurt myself \\
\hline Disconnect to the daily routine & Move to the farm \\
\hline Improve my family's life & Bad grades \\
\hline
\end{tabular}

Source: From the authors

The initiative to play with each other instead of against each other also helps to understand why $86 \%$ of the questioned adolescents said they had learned to respect their colleagues while performing a sport and the $14 \%$ who said they did not find this value in sports may have been victimized by selection processes (with the intention of selecting, categorizing the most skillfull ones), and perhaps have yet to overcome the trauma possibly experienced.

In this respect, we believe that educational sports can also serve as a corrective instrument and, over time, these students come to value their colleagues as a necessary and valuable subject for experiencing sports. Sport is one of the greatest allies in the education of any person and, in this particular case, in the rehabilitation of adolescents who may have suffered from "sport for some" instruments.

It is observed that some parents interfere hardly on their children's sporting choices, forgeting at times that their children's wishes and desires may not be the same as theirs, sometimes it seems that some parents had some frustrating experiences about sportive practices at some moment in their lives and hope to redeem in their children those feelings that were lost so many years ago. This factor can also influence beginners during the process of choosing and staying in a particular sport, which in some cases may lead to withdrawing or even leaving negative marks during this process between experiencing and selecting the best desired option.

Since $66 \%$ of the students highlighted that it were their parents who encouraged them to play sports, therefore, the paternal and maternal figure represents a big step for the future choices of children and young people, and the experience shows us the importance of assigning interpersonal relationships between parents and children in the most various sportive situations. It is in this direction that family members are responsible for analyze and evaluate some pitfalls that may be hidden in the insertion of their children in the sports world. 
It is known that one of the parents' greatest concerns about their children is working with the intellect; seeking a reference school, a good computer teacher, qualified professionals in a foreign language, in a rough way of looking at the situation, the concern revolves around the ensurance that the child becomes a young person able to pass a college entrance exam, aiming for the formation at a good university so that they can be a successful and well-paid professional so that you have a sustainable life.

It is at this moment that we are faced with a paradigm, to have a sustainable quality of life the body must work in synch with the mind, that is, so that this duality comes into accordance, the practice of physical activity through a sport or not, should be present in the life of the individual, however, however, if during a lifetime a subject was directed only to sedentary lifestyle, his insertion in some sport practice will be much more challenging. That is why it should be given attention[ to educational sport, as it will educate for life, regardless of the age at which the subject begins his or her practice.

Therefore, there is no harm in the fact that the child creates expectations of being a high level athlete, this way, these expectations must be dosed so that your desire to be an athlete does not overcome the desire to feel good with a sport, much less, that this desire will not overshadow or limit the possibilities of others participants during a class. Here, we perceive the active educational sport, which misrepresents the pursuit of excellence in sportive skills and advocates the accessibility and the right of all to enjoy this practice, without distinction of the chubbiest, thinnest, tallest, shortet, etc.

The satisfaction and the pleasure must prevail in the face of hatred and rivalry, and collective and individual sporting manifestations propagate in an educational way in pursuit of the long-awaited sport democratization and thus reach a higher number of practitioners, risking to speak of a globalization of sport.

By proposing a globalization of sport, we do not refer to millions of people shouting in one voice on behalf of a team, but we estimate an undetermined number of people who effectively use (experience) sporting practices for their personal well-being and feel as a part of the team. Acts like running, jumping, skiping, climbing, dragging, swimming, anyway, moving, are actions that should be globalized in favor of the educational sport, directing the practitioner to a conscious practice.

We seek to legitimize this educational practice inherent to sport, since some discourses regarding a "sport for all" are perceived, but there are still traces of segregating practices in sportive practive centers, where the most suitable still have privileges compared to the others' inabilities. At this point, it is realized that there is a disparity in what has been produced in the scientific field and what is established as a "pedagogical practice" in the classroom.

The spontaneity of the movements motivated by the educational sport should not be confused with the disangagement with commitment to new motor skills acquisition, it is only understood that the pedagogically organized sport has its spontaneous movements signified according to the limits of each participant, and that the differences between skills/inabilities nurture and fill gaps that exists in practice, providing the formation of a united group that plays with the differences of the other, denoting an educational dimension to the activity.

Sport can be translated into various instances such as: leisure, health, quality of life, community development, social inclusion, that is, the possibilities may be endless, however, by raising the awareness of the population for an educational sport, they will value and systematize this proposal, because consequently will be accompanied by discourses that propagate positive and humanistic values linked to physical activity.

We do not expect to imbue the ideal that educational sport satisfies the demands of contemporary society, but to demonstrate that its benefits may be the answer to present-day harms, as it has the capacity to convey positive values, and these values have the power to be transmitted in a social environment independent of any market demands, but human. 
We intercede for the dissemination of a sense of collective participation upstream the body training techniques; where adaptation sometimes runs downstream to physical activity; necessary for greater freedom in movement, a space in which the execution of an instinctive movement stands before a mechanized one. Therefore, it is important to think that due to educational level, sport respects the phenomena that surround the subjects, and thus comprises cultural aspects as elements that consider the subjectivities of practitioners; these are essential assumptions that must be considered in order to experience a sportive practice in a certain group.

Unlike selectist sports, which aims to expand more and more the number of practitioners to increase their chances of selecting high-level athletes, educational sports seeks to increase their practitioners by targeting more people to use them using this practice to improve their daily habits, producing the belief that positive values have positive powers to change the thinking and acting of the great masses.

"The sports practice requires the practitioner to learn to deal with different and even contradictory feelings. He needs to develop the ability to control the ambition to overcome challenges and the desire for victory, with the possibility of defeat" (WERTHEIN, 2004, p.118).

The indiscriminate attempt to insert children and young people in some sport without criteria of "selection" for the best teaching and learning method can generate high stress levels (The term "stress" has the sense of afliction and adversity, bearing the anguish and nuisance sensation). Only $11 \%$ of participating students reported feeling stress during the activity, while $89 \%$ said they did not suffer from it.

We agree that sport generates many emotions and its benefits are many, however, here the high stress index is synonymous with negative values in educational sport. The following chart indicates the reasons that led students to play sports.

Graph 1. Reasons that led students to play sports.
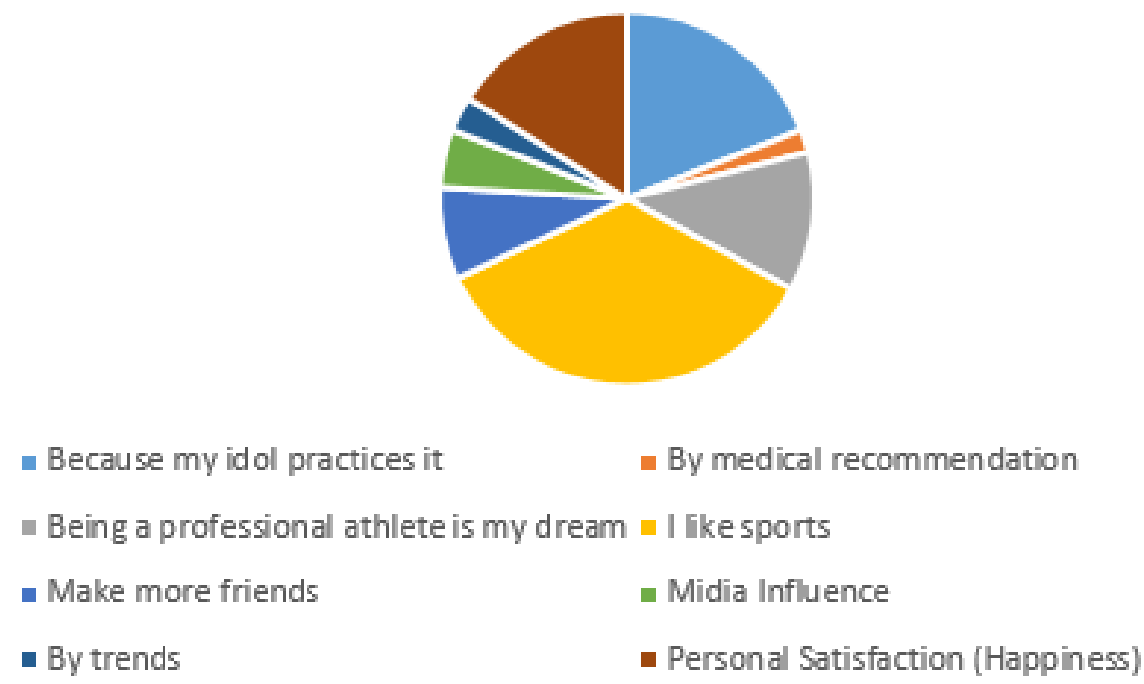

Source: Authors

Thus, in order for any activity to be carried out successfully and with the participation of all, regardless of the context in which the subjects find themselves, they must feel challenged, as the challenge manifests itself in increasing order, that is, starting with easy and the degree of difficulty is gradually increased, so this student will experience the taste of success, which we all know to be indescribable, and consequently will be motivated to taste it again. In this way, the teacher encourages and favors a pleasant experience. 
To understand the manifestations of a sport, regardless of the modality, according to Bourdieu (1990), it is necessary to recognize the position it occupies in the sports space, the sociological analysis of the distribution of the practitioners according to their position in the social space is essential.

In this context, children and young people will most likely have the opportunity to make a habit or relate to the sportive practice. Here I turn once again to Bourdieu to understand the concept of habitus and later to relate it to educational sports.

Science's division into classes leads to the common root of the classifiable practices produced by the agents and the classificatory judgments they make about the practices of others or about their own practices: habitus is, in effect, the generating principle of objectively classifiable practices and, at the same time, classification system (principiumdivisionis) of such practices. In the relationship between the two capacities that define the habitus, that is, the ability to produce practices and classifiable works, as well as the ability to differentiate and appreciate these practices and products (taste), is that is constituted the represented social world, i.e., the space of lifestyles. (BOURDIEU 2011, p.162)

In this respect, the representations of a group may resort to future realizations of certain practices or not, according to the classification system that the collective disposes for its execution. Thinking about the sportive field, what will determine the continuation or the experimentation of this phenomenon is a set of successful practices that can represent a new lifestyle for the individual or for the whole group.

A well-structured sports initiation work, taking into account pedagogical principles for sports teaching can make the difference between the bond of children or young people with sports practice or not. On this account, the fact that these subjects feel that they belong to a social group can generate pleasure in playing, creating habitus within the sports context.

Therefore, we need to consolidate the educational sport as a practice inherent in the curricula of Physical Education professionals, because it is suitable in any space and can mean the construction of more egalitarian and humane actions. Especially the dialogue between sport and education can restore the practice of healthy physical activity in many people's lives. In this respect, it can be said that we speak of a humanization of sport and that education can be a path that leads to this achievement.

\section{FINAL CONSIDERATIONS}

We understand that the educational sport is based on pedagogical principles based on positive values such as cooperation, participation, responsibility and inclusion. Acting in the development of self-esteem and integral development of the human being, and consequently favors the formation of a critical subject.

In this bias, the question arises once again: Sport for everyone or almost everyone? In order to analyze the influences of educational sports promoted in a Sports Practice Center, we understand that this sportive context increases the field of experimentation of adolescents, creating an affective bond between sport and human being, offering concrete chances of social interaction, stimulating the participation of everyone. To this end, almost everyone, or rather, perhaps some of them will come to the sport of performance, but with the certainty that they have gone through a knowledge base that led them to make the necessary decisions to specialize in one or another highly competitive sport. 
We identified several positive impacts of educational sport on the lives of children and young people participating in the study. Whether by the influence of parents, friends or teachers, sports based on education can provide the emotion that children and adolescents nowadays need to distance themselves from physical inactivity, drugs, violence, and many other negative values present in the modern world, while Speaking of these emotions, I refer to pleasant emotions, which along with them, positive values are transmitted. Therefore, teaching the student to experience certain physical activities and skills enriches his motor repertoire through the discovery of pleasure in playing sports.

The sample of this study comprised subjects registered in a formal institution that has a sport-centered program, and has specific materials for various sports modalites. However, we emphasize that the educational sport can also be developed in a non-formal and deinstitutionalized manner, adapting the physical space, the rules, the materials and especially the conditions for motor gestures. With these assumptions, we will be able to form a stronger human being, strengthening his relationship with himself and with the other; associating the feeling of overcoming with the high of social actor's self-esteem it is individuality and collectivity valued concomitantly, that is, a transcendence for sport. The results allow us to point out the need for further investigations about the role of professionals who teach sports to children and adolescents.

\section{REFERENCES}

BARBOSA, J. S., ARAÚJO, M. A. L. DE. Educação (Física) e esporte - nas teias de uma pesquisa-ação extensionista em uma universidade pública baiana. Movimento (ESEF/UFRGS), v. 21, n. 2, p. 391-403, 2015.

BARRETO, D. DE C., PERFEITO, R. S. Motivação de crianças e adolescentes praticantes de esportes em projetos de inclusão social do Rio de Janeiro. Motrivivência, v. 30, n. 53, p. 152-163, 2018.

BELTRAME, A. L. N. et al. Atendimento especializado em esporte adaptado: discutindo a iniciação esportiva sob a ótica da inclusão. Revista da Educação Física / UEM, v. 26, n. 3, p. 377-388, 2015.

BENEli, L. M., PRONI, M. W., MONTAGNER, P. C. Desafios para a Pedagogia do Esporte diante da influência do marketing na configuração do esporte contemporâneo. Journal of Physical Education, v. 27, n. 1, p. 2750 -2750, 2016.

BENTO, J. O. Do Desporto. In. Tani, G; Bento, J.O; Petersen, R. Pedagogia do Desporto. Rio de Janeiro: Guanabara Koogan, 2006.

BOURDIEU, P. Coisas Ditas: São Paulo, Brasiliense, 1990.

BRASIL, V. Z., RAMOS, V., KUHN, F., SOUZA, J. R., NASCIMENTO, J. V. Os conhecimentos de base para intervenção pedagógica do treinador de surf. Revista Brasileira de Educação Física e Esporte, v. 31, n. 4, p. 807-817, 2017.

COBRA, N. A semente da vitória. 47. ed. São Paulo: SENAC, 2003.

CONTI, M. A., FRUTUOSO, M. F. P., GAMBARDELlA, A. M. D. Excesso de peso e insatisfação corporal em adolescentes. Revista de Nutrição, Campinas, v. 18, n. 4, 2005.

ELIAS, N.; DUNNING, E. A busca da excitação. Lisboa: Memória e Sociedade, 1995.

FERREIRA, A. L. A. Estrutura e função social da atividade esportiva e o processo de apropriação da cultura: contribuições para a atividade de ensino na Educação Física escolar. Motrivivência, v. 30, n. 54, p. 295 -307, 2018.

FLORES, N. T. E., RIZZO, D. T. S., VALENÇOELA, L. P. Por uma pedagogia do treinamento esportivo infantil. Revista Panorâmica, v. 27, n.2, 2019.

FRAGA, A.B. Exercícios da informação: governo dos corpos no mercado da vida ativa. Tese de Doutorado: UFRGS, 2005.

FREITAS, M. V., STIGGER, M. P. A Formação de Crianças para o Esporte de Alto Rendimento: sobre 'manobras' e diferentes apropriações dos treinos. Pensar a Prática, v. 19, n. 1, p. 1-11, 2016.

GALATTI, L. R. et al. Esporte contemporâneo: perspectivas para a compreensão do fenômeno. Corpoconsciência, v. 22, n. 3, p. 115-127, 2018. 
GALATTI, L. R. et al. Pedagogia do Esporte: tensão na ciência e o ensino dos jogos esportivos coletivos. Revista da Educação Física/UEM, v. 25, n. 1, p. 153, 2014.

GO TANI et al. O ensino de habilidades motoras esportivas na escola e o esporte de alto rendimento: discurso, realidade e possibilidades. Revista Brasileira de Educação Física e Esporte, v. 27, n. 3, p. 507-518, 2013.

LEONARDI, T. J. et al. Pedagogia do esporte: sinalização para a avaliação formativa da aprendizagem. Pensar a Prática, v. 20, n. 1, 2017.

LIMENA, M. M. C., RODRIGUES, M. L. Metodologias multidimensionais em ciências humanas. Brasília: Liber Livro, 2006.

LINHARES, M. A. A escola, o esporte e a "energização do caráter": projetos culturais em circulação na Associação Brasileira de Educação (1925-1935). Tese de Doutorado UFMG, 2006.

LUGUETTI, C. N. et al. O planejamento das práticas esportivas escolares no ensino fundamental na cidade de Santos. Revista Brasileira de Ciências do Esporte, v. 37, n. 4, p. 314-322, 2015.

MACDONALD, D. J., CôTÉ, J., EYs, M., DEAKIN, J. Psychometric properties of the youth experience survey with young athletes. Psychology of Sport and Exercise, v. 13, n. 3, p. 332-340, 2012.

MACHADO, G. V., GALATTI, L. R., PAES, R. R. Pedagogia do esporte e projetos sociais: interlocuções sobre a prática pedagógica. Movimento (ESEF/UFRGS), v. 21, n. 2, p. 405-418, 2015.

MACHADO, R. B. Políticas de inclusão e a docência em educação física: uma reflexão sobre as práticas. Revista Brasileira de Ciências do Esporte, v. 39, n. 3, p. 261-267, 2017.

MAHONEY, H. A., ECCLES, J. Organized Activity Participation, Positive Youth Development, and the OverScheduling Hypothesis. Social Policy Report, v.20, n.4, p.3-30, 2006.

MINAYO, M. C. S. O desafio do conhecimento: pesquisa qualitativa em saúde. 4. ed. São Paulo/Rio de Janeiro: HUCITEC/ABRASCO, 2004.

NASCIMENTO, J. C.; RIZZO, D. T. S.; SOUSA, A. P. M. O pole dance como prática esportiva na escola. Revista Magsul de Educação Física na Fronteira, v. 1, n. 1, 2017.

OLIVEIRA, V. M. O esporte pode tudo. São Paulo: Cortez, 2010.

PAES, R. R., BALBINO, H. F. Pedagogia do Esporte: contextos e perspectivas. Rio de Janeiro: Guanabara Koogan, 2005.

PAZIN, N. P. A., FREITAS, D. P. A., SILVA, M. L. Esporte para Todos e a constituição de um projeto de intervenção social. Revista Metáfora Educacional, v.9, n.1, p.18-30, 2010.

RIZZO, D. T. DE S. et al. Esporte e inclusão: por uma prática pedagógica “educacional”. American Journal of Sports Training, v. 1, n. 3, p.1-16, 2016a.

RIZZO, D. T. S. Esporte para todos ou quase todos? considerações sobre a prática esportiva educacional. 1. ed. Ponta Porã-MS: EdFAMAG, 2017.

RIZZO, D. T. S.; ARANHA, ÁGATA C. M.; FREITAS, C. M. S. M.; SOUSA, A. P. M.; RAMIRES, J. M.; LOPES, J. C. Concepções de gestores e monitores sobre o esporte no Programa Mais Educação: por uma pedagogização da prática esportiva. Revista Produção e Desenvolvimento, v.2, n.1, p.1-9, 2016b. https://doi.org/10.32358/rpd.2016.v2.118

RODRIGUES, M. L., LIMENA, M. C. Metodologias multidimensionais em Ciências Humanas. Brasília: Líber Livros Editora, 2006.

SCAGLIA, A. J. A pedagogia do esporte e as novas tendências metodológicas. Nova Escola, v. 29, p. 84-86, 2014.

SOARES, A. J. G., MILlEN NETO, A. R., FERREIRA, A. DA C. A pedagogia do esporte na educação física no contexto de uma escola eficaz. Revista Brasileira de Ciências do Esporte, v. 35, n. 2, p. 297-310, 2013.

SOARES, J. A. P., ANTUNES, H. R. L., AGUIAR, C. F. DOS S. Prática desportiva e sucesso escolar de moças e rapazes no ensino secundário. Revista Brasileira de Ciências do Esporte, v. 37, n. 1, p. 20-28, 2015.

STIGGER, M. P. Esporte, Lazer e Estilos de Vida: um estudo etnográfico. Campinas: Autores Associados, 2002.

STIGGER, M. P., LOVISOLO, H. R. Esporte de rendimento e esporte na escola. Campinas: Autores Associados, 2009.

TUBINO, M. J. G., COSTA, V. L. M. Práticas populares de esporte na praia: estudos dos jogos de frescobol. In VOTRE, Sebastião Josué (Org.) et al. Cultura, Atividade Corporal e Esporte. Rio de Janeiro: Editoria Central da Universidade Gama Filho, 1995. 
VIANNA, J. A., LOVISOLO, H. R. Projetos de Inclusão Social através do esporte: notas sobre a avaliação. Movimento, v. 15, n. 3, p. 145-162, 2009.

WERTHEIN, J. Esporte: uma estratégia para a vida. In: ROSA, M. R. Esporte e Sociedade: ações socioculturais para a cidadania. São Paulo: IMK Relações Públicas, 2004.

All authors stated that they had: a) actively participated in the discussion of the results; and b) Review and approval of the final version of the paper.

This work is licensed under a Creative Commons Attribution 4.0 International License. CC-BY 